\title{
IMPROVING STUDENTS’ LANGUAGE SKILLS IN BUSINESS ENGLISH COURSE: EXPERIMENTAL STUDY
}

\author{
Zuzana Hrdličková \\ University of Economics in Bratislava, Faculty of Applied Languages, Slovakia \\ zuzana.hrdlickova@euba.sk
}

\begin{abstract}
It is evident from the PISA 2018 results that a trend in mean performance in reading has been declining in the Slovak Republic. The KEGA Project "Idioms in Business Communication", run at the Department of English Language, aims at improving reading literacy, widening formal and informal vocabulary and facilitating business communication. Both traditional and modern styles of language teaching are used. The control group of students does a traditional course and the experimental group of students enrols in a "Business Communication" e-course on LMS Moodle platform, as well. With the use of the Internet and supporting materials, this group is involved in various activities. The paper compares the study results of 144 first-year and 97 second-year students of the University of Economics in Bratislava achieved in departmental standardised business English tests after completing three courses in business English for advanced students. The method of Hypothesis Testing (t-Test) assesses the significance of the difference between the levels of knowledge of both groups. The research findings prove that the experimental group of students achieved better results in final evaluation than the control group of students. The results also confirm that an alternative form of business English teaching was effective.
\end{abstract}

Keywords: reading text; business term; idiomatic expression; reading literacy; LMS Moodle; blended learning; summary.

\section{Introduction}

In each round of the Programme for International Student Assessment (PISA), one subject is tested in detail. In the seventh assessment, in 2018, 79 countries and economies participated in it and the main subject was reading, as it was in 2000 and 2009. The data (OECD, 2019a) tell us that seven countries or economies, including the Slovak Republic, saw declining mean performance across all three subjects. Regarding the performance in reading, Slovak participants achieved unsatisfactory results in the assessments in 2003, 2006, 2009 and 2012. In addition, mean performance in reading along with science did not change significantly between 2015 and 2018. When comparing countries and economies' performance in reading in the last assessment, the Slovak Republic is in the 41st place, i.e. statistically significantly below the OECD average.

The data also indicates that there is a close inter-relationship between a student's performance in PISA and his/her parents' level of education (as measured by their educational qualifications). Countries with more highly educated and skilled adults are at an advantage over countries where parents have less education, or where many adults have low literacy skills (OECD, 2019a). In the past, proficiency in reading, writing and arithmetic made a solid foundation for young adults entering university or launching a career. The definition of literacy has stretched; it means education, knowledge or skill in a particular area, as well.

Not only Slovak pupils or high-school students but also undergraduates face problems when working with reading texts. Therefore, reading literacy needs to be improved in higher education.

Many scholars deal with the issue of whether the language of the text affects first- or second-language readers (Alderson, 2000). Schlesinger (1986) investigates whether syntactic complexity causes processing difficulties for readers. Berman (1984) discusses a number of linguistic variables that make texts harder to process for readers, e.g. the opacity and heaviness of the constituent structure of sentences. Vocabulary difficulty has consistently been shown to have an effect on understanding for readers (Freebody \& Anderson, 1983). It has also been shown that topic (un)familiarity cannot be compensated for by easy vocabulary: both difficult vocabulary and low familiarity reduce comprehension. Lexical complexity, especially the meanings of idiomatic expressions, make texts hard for readers (Williams \& Dallas, 1984). Homonyms are especially hard to process, as readers seem to fix on one meaning, but do not detect lack of fit in the context (Cooper, 1984) (cf. Hrdličková, 2017).

Gilakjani and Sabouri (2016) explore the factors affecting learners' reading comprehension skill like complexity of the reading text, anxiety during reading activities, interest and motivation, decoding, environmental influences and medical problems. They list good reader strategies, such as predicting, deducing, summarizing, examining and evaluating and suggest useful strategies for improving this skill.

(C) Zuzana Hrdličková. 2021. Published by Igor Sikorsky Kyiv Polytechnic Institute. This is an Open Access article distributed under the terms of the licence CC BY 4.0 
It has long been known that vocabulary load and lexical complexity are major predictors of text difficulty. As far as idiomatic expressions in English are concerned, they include collocations (Hoey, 2015; Nattinger \& DeCarrico, 1992; Sonomura, 1996), phrasal verbs (Kačmárová, 2011; Hrdličková, 2016a), idioms (full idioms, semi-semi idioms and quasi-idioms) metaphors, hyperboles, similes, proverbs and sayings, speech formulae, situation-bound utterances and clichés (Moon, 1998; Strässler, 1982; Mel'čuk, 2012; Kecskes, 2013; Sonomura, 1996; Quirk et al., 1985). Fernando (1996) describes ideational, interpersonal and relational idiomatic expressions and she utters that proper understanding of ideational idiomatic expressions in communication is difficult for non-native speakers as their meanings cannot be derived from the meanings of individual components.

Bilá et al. (2015) provide a summary of findings and approaches to the issue of multi-word expressions in lexicological compendiums, textbooks and lexicographical works, as well as in selected scholarly works in English, German, Romance and Hispanic Studies, primarily based on the comparison with the Slovak language. They provide analyses of approaches to the multi-word expressions as compared to Slovak Studies, classifications of multi-word expressions in the language at issue. In addition, they present lexicographical inclusions of multi-word expressions in different types of dictionaries and indicate the problems in the translating of Slovak multi-word expressions into English, German, French and Spanish.

Bilá (2016) also deals with symmetries and asymmetries between English and Slovak multi-word expressions (economic terminology) with regard to the number of structural components, their syntactic patterning and conceptualization. In her study, she tries to find out how genetic typological and cultural differences between English and Slovak influence the structure and semantics of multi-word expressions in the area of economics. One of the problems of translation into Slovak is the question which term should be preferred - motivated or unmotivated. In her view, reasons for preferring the motivated term can be found in tradition as well as in practical needs.

Spišiaková $(2017,2018)$ and Adamcová (2020) analyse and compare Spanish, German and English idiomatic expressions in professional texts. In their view, these expressions cause problems for interpreters in translation as well as for learners in the acquisition and correct usage. Rusiňáková (2018) and Maierová (2018) explore idiomatic expressions in the fields of economics, diplomacy, international trade, marketing and advertising. According to them, idioms are used in different types of discourse due to their attractiveness and memorability. On the other hand, they state that idiomatic expressions can present certain problems for non-native speakers and thus they pay attention to the ways of how undergraduates can master them.

Many empirical studies on the acquisition of collocations (e.g. Peters, 2014, 2015; Webb, Newton, \& Chang, 2013) have examined intentional learning through explicit teaching and learning. Peters' studies $(2014,2015)$ reveal that intentional learning through various activities is effective for the acquisition of second-language collocations. Pellicer-Sánchez (2015) explores the incidental acquisition of collocation knowledge when readers come across collocations. Her study demonstrates the effectiveness of reading for the incidental learning of the form and meaning of unknown single words. Results also show that reading can improve learners' knowledge of the form of collocations. This also supports and expands results of Webb, Newton, \& Chang (2013), suggesting that reading-only treatment can lead to the acquisition of collocations.

As for the graduates of the University of Economics in Bratislava (EU BA), employers require them to improve both written and spoken communication, especially business correspondence as well as conversation and presentation skills. Undergraduates are expected to master vocabulary in the areas of business, finance, banking, accounting, taxes, marketing, controlling and international trade (Spišiaková \& Kittová, 2020). As it can be seen, the requirement of the employers corresponds with Breeze's (2007) research findings that university-level foreign language courses often provide undergraduates with only inadequate preparation. She states that there are several reasons for this, for example, large class sizes, mixed level groups, but it is evident that one of the main problems is the lack of clear teaching objectives after a B2 level of general foreign language competence has been reached. Courses for students in the fields of business, management or engineering need to be organised with the purpose of promoting C1-level competence within the specific professional target area. The competences should underpin the basic functional, lexical and structural syllabus of the course determining what kind of language is taught and learnt. We absolutely agree with Breeze (2007), Donna (2000), and Taylor (2006) that apart from acquiring terminology, lecturers should put emphasis on practising and acquiring skills in the specific contexts of business, management or engineering, rather than on de-contextualised language practice.

To be literate economically, financially, technologically, etc. is very important. Nowadays, top literacies in education are digital, media, information, financial, health, multi-cultural, emotional and others. Some literacies are familiar, some are fresh, but all of them are interrelated. Reading literacy, one of the basic literacies, is defined as students' "capacity to understand, use, evaluate, reflect on and engage with texts in 
order to achieve one's goals, develop one's knowledge and potential and participate in society." (OECD, 2019 b, p.14). Delgadová (2015) regards it as one of the most significant academic competences for university students. In her research, she tests a small group of Slovak first-year university students and the results indicate reading literacy deficiencies, i.e. students are insufficiently prepared to deal with academic texts of intermediate level of complexity, and lack analytical and critical thinking.

The past decade has been a period of rapid digitalisation. The fast digitalisation of communication is having an extensive impact on the kind of information literacy that young adults will need to demonstrate in their future jobs and in their wider social interactions. Progressing technologies have changed the way people read and exchange information, whether at home, at school or in the workplace. The rapidly changing world, including rapid advances in science and technology, points to the growing demand for digital skills and competences. The development of digital skills and competences thus not only represents the basis for the effective digital transformation in education, but also strengthens the profile of the graduate who is able to successfully participate in society.

Universities around the world use modern information and communication technologies (ICT) in order to improve the quality of the teaching-learning process as well as to contribute to the development of students' skills. The benefits of teaching foreign languages via blended learning have been accrued. Shaykina (2015) writes about the modernisation of Russian education. In her view, blended learning in English Language Teaching (ELT) can enhance the effectiveness of the process itself. She lists open educational resources such as Moodle, GoConqr, Emaze, HumBox, and Scoop.it and says that Moodle is one of the most effective resources used at the University.

English is the most often taught foreign language at universities in Croatia. Lasić-Lazić, Ivanjko, \& Grubješić (2017) state that blended learning can significantly improve the learning experience. According to them, Moodle offers a wide range of activities that can be implemented in English for Professional Purposes (EPP) Teaching: Chat, Database, Forum, Hot potatoes, Journal, Lesson/Lecture, Questionnaire, Survey, Dictionary, Shareable Content Object Reference model (SCORM), Wiki, Assignment and Workshop.

Tang (2013) also does research into blended learning. In his view, modern technologies, e.g. the Moodle platform, make it feasible to conduct it. He discusses listening, speaking, reading, writing and translating activities that ESL learners (English as a Second Language) can develop via blended learning.

Gluchmanova (2016) tries to raise the level of vocational education in foreign languages via innovative forms of e-learning and with the use of Moodle as well as the latest ICT. Most students expressed greater satisfaction from engagement in learning. Her approach to ELT has proven to be successful.

Due to the fast digitalisation, Slovak undergraduates have higher digital literacy, which gives them an advantage. The KEGA Project "Idioms in Business Communication" was designed to help them develop reading literacy via LMS Moodle and to improve their language and social skills.

The aim of the study is to compare the students' results achieved in departmental standardised business English tests. Students followed both traditional and alternative forms of language teaching. While the control group of students only used a coursebook, the experimental group of students also worked with a self-study reference and practice book "Ideational Idioms in Business English Communication" (Hrdličková, 2016b). In addition, this group of students was enrolled on a "Business Communication" e-course in LMS Moodle, where they did different assignments, e.g. writing summaries, practising tenses in grammar exercises and reading professional articles in online versions of newspapers/magazines.

Since the teaching and learning process was enhanced by ICT, the experimental group of students was expected to achieve better study results than the control group of students. The paper aims at testing the difference between the achieved results in academic years 2017/2018 and 2018/2019 via two hypotheses:

Null Hypothesis $\left(\mathrm{H}_{0}\right)$ : The difference between the study results of both groups is not significant (the level of knowledge is not different).

Alternative Hypothesis $\left(\mathrm{H}_{1}\right)$ : The difference between the study results of both groups is significant (the level of knowledge is different).

\section{Methods}

\section{Participants}

To confirm the effectiveness of an alternative form of teaching using "Ideational Idioms in Business English Communication", the Internet and LMS Moodle, a pedagogical experiment was performed at the Department of English Language in 2019. First- and second-year students of the Faculty of National Economy, the Faculty of International Relations and the Faculty of Commerce participated in the experiment. Increasing students' motivation to study English and gaining better study results was the essence of the pedagogical experiment. Altogether, 241 students were tested in this research. In the academic year 
2017/2018, 74 students were included in the experimental group and 70 students in the control group. In 2018/2019, 64 students formed the experimental group and 33 students the control group.

\section{Materials and procedure}

All participants signed up for three courses "Business English for Advanced Students I, II and III". The control group of students did traditional courses, i.e. they used "Market Leader Business English Course Book" (Cotton, Falvey, \& Kent, 2011). The experimental group of students also did traditional courses but these were supported by an e-course "Business Communication". Via the Internet and LMS Moodle, they developed their reading literacy in English and improved business communication.

During the first semester, all participants acquired business terms and idiomatic expressions from Units 1-4 (Communication, International marketing, Building relationships and Success). The experimental group of students acquired formal and informal vocabulary from a self-study reference and practice book (Hrdličková, 2016b), too. What is more, they started to work in LMS Moodle and sent short summaries of reading texts in the coursebook (see Appendix 1) to their lecturers to receive feedback. By doing this assignment, they started to prepare for one of the tasks in a departmental standardised business English test. Finally, both groups of students were tested on idiomatic expressions (see Appendix 2).

In the second semester, the students continued in the same kind of work. However, each student of the experimental group was supposed to read 12 professional articles from the fields of economics, diplomacy and law. They chose the following sources: The Guardian, Forbes, Newsweek, The Economic Times, Foreign Affairs, The Diplomat, The Economist, The Telegraph, The New York Times, Politico, Business New Daily, Business Insider, Elite Business, Marketing Week, MoneyWeek, Adweek, The Independent, Fortune, Inc., Express, The Sun, Student News Daily, ThoughtCo., Cable News Network, British Broadcasting Corporation, Bloomberg, Business Weekly, National Public Radio, Reuters, The American Spectator, The Washington Post, and US News. Lecturers recommended students to use strategies such as predicting, summarizing, clarifying, etc. to improve their reading comprehension skills. They analysed articles for idioms and unknown words and identified their meanings with the help of print or online versions of English-language dictionaries like en.oxforddictionaries.com, dictionary.cambridge.org, merriamwebster.com, idioms.thefreedictionary.com and many more. Then, they submitted their homework into LMS Moodle. Lecturers provided the students with immediate feedback as well as highlighted business terms that were important to acquire during the semester. To identify idioms, economic concepts, and legal concepts, lecturers consulted dictionaries and reference books by the following authors and editors: Law (2015), Gillet (2010), O'Dell and McCarthy (2010), O'Dell and McCarthy (2008), Walter (2006), Parkinson and Noble (2005), McCarthy and O'Dell (2005), McCarthy and O'Dell (2002) and Cowie, Mackin, and McCaig (1993). After receiving feedback, they had to prepare for a mini-presentation of each article.

In the third semester, both groups of students dealt with Units 9-12 (Raising money, Customer service, Crisis management and Mergers and acquisitions. Again, each student of the experimental group was supposed to read 12 newspaper/magazine articles and do the same work as in the second semester. Economics and Law students searched for legal terms in sources such as New Law Journal and The Law Society Gazzette.

\section{Data analysis}

At the end of the first and third semesters, both control and experimental groups of students did standardised business English tests (see Appendix 3). To compare the level of knowledge acquired in business English courses and the achieved results/grades, the method of Hypothesis Testing has been chosen. An Independent Samples t-Test (or 2-Sample t-Test) assesses the significance of the difference between the sample means, while the samples are of a large scale (Kučerová \& Fidlerová, 2012).

\section{Results}

In order to analyse the achieved results, i.e. to compare the level of students' knowledge, the method of Hypothesis Testing has been chosen. A parametric test, the so-called t-Test, aimed at testing the significance of the difference between the sample means is used.

Table 1, Table 2 and Figure 1 show the grades (absolute and relative frequencies) achieved in a standardised business English test in 2018/2019 by 64 students of the experimental group and 33 students of the control group as well as the graphic representation of achieved grades. Table 3, Table 4 and Figure 2 show the grades (absolute and relative frequencies) achieved in a standardised business English test in $2017 / 2018$ by 74 students of the experimental group and 70 students of the control group as well as the graphic representation of achieved grades. (ECTS - European Credit Transfer and Accumulation System). 
Table 1. The grades achieved in a standardised business English test in 2018/2019

\begin{tabular}{|l|c|c|c|c|c|c|}
\hline \multirow{2}{*}{$\begin{array}{l}\text { Group } \\
\text { of students }\end{array}$} & \multicolumn{7}{|c|}{ EU BA and ECTS Grades (absolute frequency) } \\
\cline { 2 - 7 } & $\begin{array}{c}1-\mathrm{A} \\
\text { Excellent }\end{array}$ & $\begin{array}{c}1,5-\mathrm{B} \\
\text { Very good }\end{array}$ & $\begin{array}{c}2-\mathrm{C} \\
\text { Good }\end{array}$ & $\begin{array}{c}2,5-\mathrm{D} \\
\text { Satisfactory }\end{array}$ & $\begin{array}{c}3-\mathrm{E} \\
\text { Sufficient }\end{array}$ & $\begin{array}{c}4-\mathrm{FX} \\
\text { Failed }\end{array}$ \\
\hline Experimental & 11 & 16 & 15 & 18 & 4 & 0 \\
\hline Control & 5 & 5 & 8 & 8 & 6 & 1 \\
\hline Source: Own & \multicolumn{7}{|c|}{} \\
\hline
\end{tabular}

Table 2. The grades achieved in a standardised business English test in 2018/2019

\begin{tabular}{|l|c|c|c|c|c|c|}
\hline \multirow{2}{*}{$\begin{array}{l}\text { Group } \\
\text { of students }\end{array}$} & \multicolumn{7}{|c|}{ EU BA and ECTS Grades (relative frequency) } \\
\cline { 2 - 7 } & $\begin{array}{c}1-\mathrm{A} \\
\text { Excellent }\end{array}$ & $\begin{array}{c}1,5-\mathrm{B} \\
\text { Very good }\end{array}$ & $\begin{array}{c}2-\mathrm{C} \\
\text { Good }\end{array}$ & $\begin{array}{c}2,5-\mathrm{D} \\
\text { Satisfactory }\end{array}$ & $\begin{array}{c}3-\mathrm{E} \\
\text { Sufficient }\end{array}$ & $\begin{array}{c}4-\mathrm{FX} \\
\text { Failed }\end{array}$ \\
\hline Experimental & $17.2 \%$ & $25.0 \%$ & $23.4 \%$ & $28.1 \%$ & $6.3 \%$ & $0.0 \%$ \\
\hline Control & $15.2 \%$ & $15.2 \%$ & $24.2 \%$ & $24.2 \%$ & $18.2 \%$ & $3.0 \%$ \\
\hline Source: Own & \multicolumn{7}{|c|}{} \\
\hline
\end{tabular}

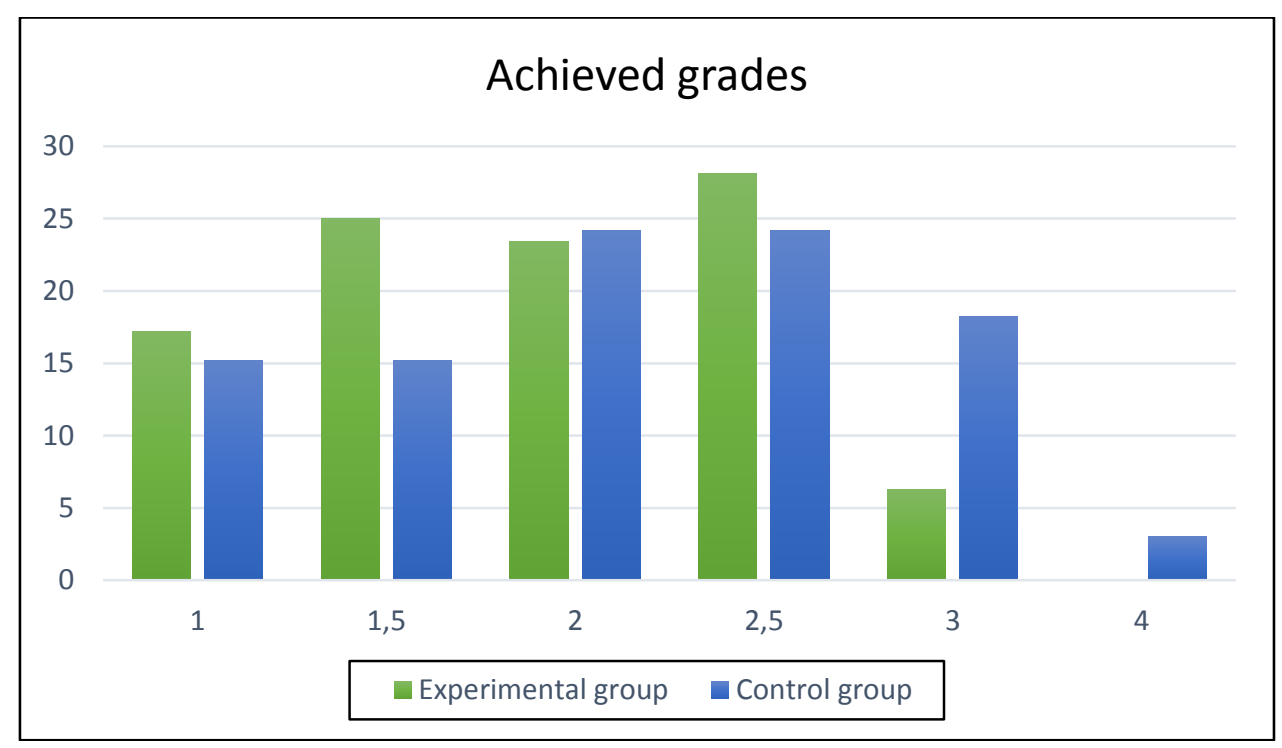

Figure 1. The graphic representation of achieved grades

Table 3. The grades achieved in a standardised business English test in 2017/2018

\begin{tabular}{|l|c|c|c|c|c|c|}
\hline \multirow{2}{*}{$\begin{array}{l}\text { Group } \\
\text { of students }\end{array}$} & \multicolumn{6}{|c|}{ EU BA and ECTS Grades (absolute frequency) } \\
\cline { 2 - 7 } & $\begin{array}{c}1-\mathrm{A} \\
\text { Excellent }\end{array}$ & $\begin{array}{c}1,5-\mathrm{B} \\
\text { Very good }\end{array}$ & $\begin{array}{c}2-\mathrm{C} \\
\text { Good }\end{array}$ & $\begin{array}{c}2,5-\mathrm{D} \\
\text { Satisfactory }\end{array}$ & $\begin{array}{c}3-\mathrm{E} \\
\text { Sufficient }\end{array}$ & $\begin{array}{c}4-\mathrm{FX} \\
\text { Failed }\end{array}$ \\
\hline Experimental & 3 & 10 & 11 & 17 & 23 & 10 \\
\hline Control & 4 & 11 & 13 & 22 & 17 & 3 \\
\hline
\end{tabular}

Table 4. The grades achieved in a standardised business English test in 2017/2018

\begin{tabular}{|l|c|c|c|c|c|c|}
\hline \multirow{2}{*}{$\begin{array}{l}\text { Group } \\
\text { of students }\end{array}$} & \multicolumn{6}{|c|}{ EU BA and ECTS Grades (relative frequency) } \\
\cline { 2 - 7 } & $\begin{array}{c}1-\mathrm{A} \\
\text { Excellent }\end{array}$ & $\begin{array}{c}1,5-\mathrm{B} \\
\text { Very good }\end{array}$ & $\begin{array}{c}2-\mathrm{C} \\
\text { Good }\end{array}$ & $\begin{array}{c}2,5-\mathrm{D} \\
\text { Satisfactory }\end{array}$ & $\begin{array}{c}3-\mathrm{E} \\
\text { Sufficient }\end{array}$ & $\begin{array}{c}4-\mathrm{FX} \\
\text { Failed }\end{array}$ \\
\hline Experimental & $4.0 \%$ & $13.5 \%$ & $14.9 \%$ & $23.0 \%$ & $31.1 \%$ & $13.5 \%$ \\
\hline Control & $5.7 \%$ & $15.7 \%$ & $18.6 \%$ & $31.4 \%$ & $24.3 \%$ & $4.3 \%$ \\
\hline
\end{tabular}




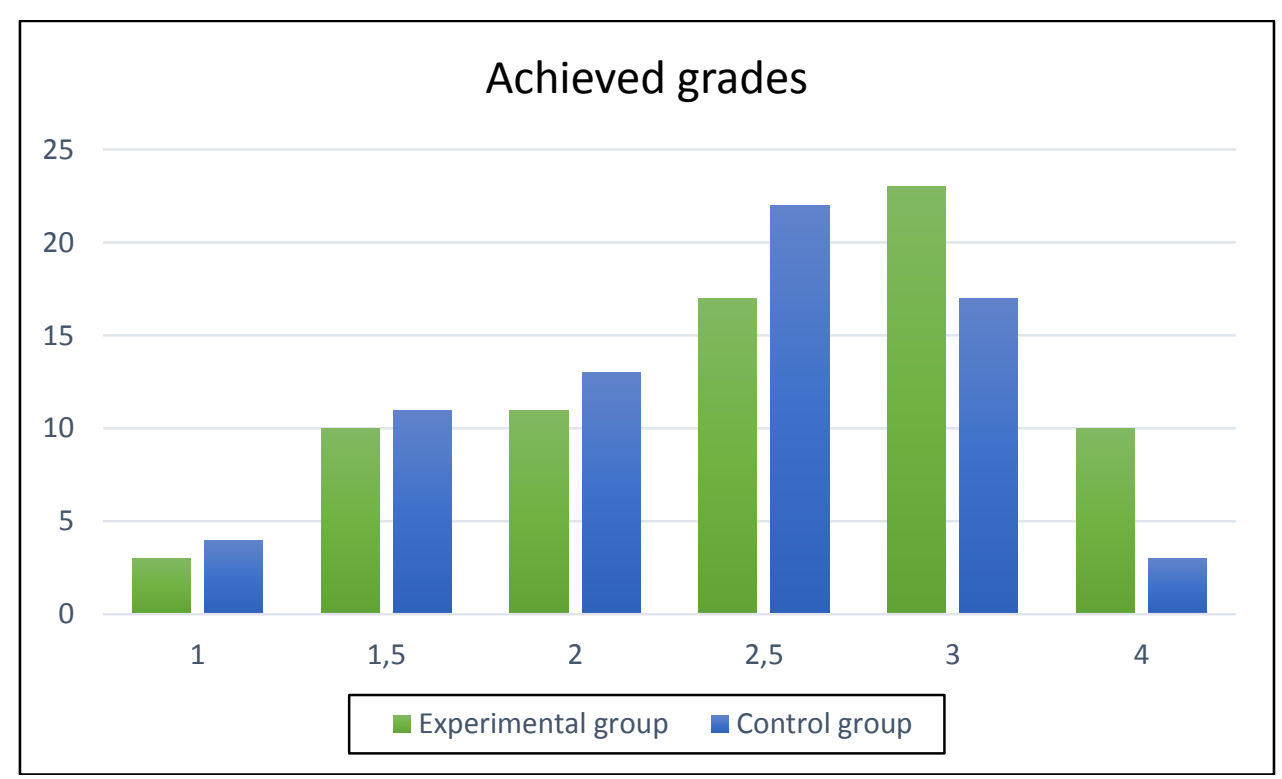

Figure 2. The graphic representation of achieved grades

Table 5. The difference between the study results of the experimental group of students in a standardised business English test

\begin{tabular}{|l|r|r|}
\hline Academic year & $\mathbf{2 0 1 8 / 2 0 1 9}$ & $\mathbf{2 0 1 7 / 2 0 1 8}$ \\
\hline Expected value & 1.91 & 2.53 \\
\hline Variance & 0.3641 & 0.6636 \\
\hline Observation & 64 & 74 \\
\hline $\begin{array}{l}\text { Hypothetical difference of expected } \\
\text { values }\end{array}$ & 0 & \\
\hline Difference & 133 & \\
\hline Test statistics & -5.12759 & \\
\hline $\mathrm{P}(\mathrm{T}<=\mathrm{t})(1)$ & 0.0000005 & \\
\hline $\mathrm{t}$ crit $(1)$ & 1.656391 & \\
\hline $\mathrm{P}(\mathrm{T}<=\mathrm{t})(2)$ & 0.000001 & \\
\hline $\mathrm{t}$ crit $(2)$ & 1.977961 & \\
\hline
\end{tabular}

The finding: On the level of significance at 5\% $(\alpha=0.05)$, the null hypothesis $\left(\mathrm{H}_{0}\right)$ is rejected, since the probability $\mathrm{p}=0.000001$ (i.e. $\mathrm{p}<\alpha$ ), i.e. the difference can be considered as significant.

Table 6. The difference between the study results of the control group of students in a standardised business English test

\begin{tabular}{|l|r|r|}
\hline Academic year & $\mathbf{2 0 1 8 / 2 0 1 9}$ & $\mathbf{2 0 1 7 / 2 0 1 8}$ \\
\hline Expected value & 2.14 & 2.35 \\
\hline Variance & 0.5511 & 0.4574 \\
\hline Observation & 33 & 70 \\
\hline $\begin{array}{l}\text { Hypothetical difference of expected } \\
\text { values }\end{array}$ & 0 & \\
\hline Difference & 55 & \\
\hline Test statistics & -1.41187 & \\
\hline $\mathrm{P}(\mathrm{T}<=\mathrm{t})(1)$ & 0.081811 & \\
\hline $\mathrm{t}$ crit $(1)$ & 1.673034 & \\
\hline $\mathrm{P}(\mathrm{T}<=\mathrm{t})(2)$ & 0.163622 & \\
\hline $\mathrm{t}$ crit $(2)$ & 2.004045 & \\
\hline
\end{tabular}


The finding: On the level of significance at 5\% $(\alpha=0.05)$, the null hypothesis $\left(\mathrm{H}_{0}\right)$ is not rejected $\left(\right.$ or $\mathrm{H}_{0}$ is retained), since the probability $\mathrm{p}=0.163622$ (i.e. $\mathrm{p}>\alpha$ ), i.e. the difference can be considered as random, or it is not statistically significant.

When comparing the study results of the experimental group of students (Table 5) in both academic years 2017/2018 and 2018/2019, on the basis of a t-Test it can be asserted that the difference between the achieved results/grades is statistically significant.

When comparing the study results of the control group of students (Table 6) in both academic years 2017/2018 and 2018/2019, on the basis of a t-Test it can be asserted that the difference between the achieved results/grades is not statistically significant.

\section{Discussion}

Both groups of students (experimental and control) took standardised business English tests in the first and third semesters. Due to applying technology in the teaching and learning process, the experimental group of students was supposed to achieve better results than the control group of students. To test the significance of the difference between the sample means, while the samples were of a large scale, an Independent Samples t-Test (or 2-Sample t-Test) was used.

Regarding the hypotheses, on the level of significance at $5 \%(\alpha=0.05)$, the null hypothesis $\left(\mathrm{H}_{0}\right)$ is rejected, since the probability $\mathrm{p}<\alpha$, i.e. the difference can be considered as significant. In addition, when comparing the study results of both groups in both academic years 2017/2018 and 2018/2019, on the basis of a t-Test it can be stated that the difference between the achieved results/grades is statistically significant.

Tables 5 and 6 clearly demonstrate the benefits of an alternative form of language teaching. We strongly agree with Delgadová (2015) who states that university students are not sufficiently prepared to work with academic texts. She develops reading literacy and focuses on two genres used in the academic setting writing abstracts and making PowerPoint presentations. We also focus on developing reading, writing and presentations skills (cf. Spišiaková \& Kittová, 2020). Our research proves that implementing LMS Moodle into the teaching and learning process was a right and wise decision. It was a stimulating environment for the independent nature of learning. Undergraduates enjoyed working with articles, doing written assignments (summaries/grammar exercises) and communicating in LMS Moodle. Lecturers' feedback on business terms, legal terms and idiomatic expressions helped them enrich their vocabulary (Hrdličková, Rusiňáková, \& Maeirová, 2019) and after receiving feedback, they felt quite confident while giving mini-presentations.

We also agree with Hakim, Abidin, and Bahari (2020) who say that dictionary usage is one of the potential vocabulary learning strategies in developing a learning process. Working with authentic texts, looking for idiomatic expressions in them and identifying their meanings with the use of an e-dictionary can be an effective alternative to make seminars more appealing to them. Many students expressed a growing interest in learning idiomatic expressions that was confirmed in idiomatic tests (cf. Hrdličková, 2018).

Naturally, while carrying out this project, there were some limitations - not all lecturers were enthusiastic about using technology in the process itself. Also, many first-year students struggled to pass examinations from core university courses and therefore devoted more time to them than to business English. Even though it was a bit complicated for some of them to use LMS Moodle at the beginning, it needs to be emphasised that undergraduates are technologically skilful and according to nearly all of them the virtual learning environment LMS Moodle was convenient and easy to use.

\section{Conclusions}

Communication is very important not only in privacy but also in professional life. Within the KEGA Project, the participants had the chance to improve communication. The current coursebook includes reading texts containing a large number of idiomatic expressions. A self-study reference and practice book provided the experimental group of students with an overview of basic business terms and 319 idioms from contemporary British, American and Australian English along with their definitions and, in case of idioms, with their meanings, non-idiomatic equivalents as well as Slovak equivalents. Our previous research into acquiring idioms (cf. Hrdličková, 2018) indicates that they liked learning this type of vocabulary.

Since the traditional courses in business English were supported by an e-course in LMS Moodle, the experimental group of students was supposed to achieve better study results than the control group of students. Surprisingly, the research findings in 2017/2018 show that the experimental group of students achieved worse results than the control group of students. One of the main reasons was the fact that this group was not as bright as the control group of students and many students left university during the first year of study. The second reason was the fact that the experimental group of students had to follow two textbooks at the same time. While working with a self-study reference and practice book (written in an 
academic style), they dealt with unfamiliar topics, saw many unknown words and struggled with their pronunciation. Thirdly, they focused on terms frequently used in business communication, not on less important business vocabulary. Finally, they primarily aimed at passing examinations from the core university courses and thus devoted less time to studying business English for the written examination.

In the second and third semesters, the lecturers tried to improve students' reading literacy through working with online English-language newspapers/magazines articles. It must be emphasised that apart from reading literacy, the students developed digital, media, information, cultural and intercultural literacies.

As the research findings in 2018/2019 are concerned, the difference between the level of students' knowledge was statistically significant. In the third semester, the experimental group of students was more committed to doing extra individual work in business English seminars, which definitely benefited them.

To sum up, lecturers need to be devoted to using modern technologies as they facilitate blended learning. LMS Moodle is an invaluable asset in the teaching and learning process. It also supports the major features of Communicative Language Learning, e.g. the learner autonomy, alternative assessment, diversity, and so on. Moreover, LMS Moodle is a great platform for testing. This academic year, students of the Faculty of International Relations took online examinations from the course "British, American and Slovak Studies". Many activities that can be done through LMS Moodle or open educational resources, which are mentioned in the paper, will be explored in the future to improve learners' skills and to broaden their knowledge.

\section{Acknowledgements}

The paper is part of the KEGA Project 015EU-4/2017 Idioms in Business Communication (Idiomatické výrazy v obchodnej komunikácii), subsidised by the Ministry of Education, Science, Research and Sport of the Slovak Republic.

\section{References:}

Adamcová, S. (2020). Empirical Research of Collocations in Foreign Language Learning. Advanced Education, 14, 75-83. https://doi.org/10.20535/2410-8286.197363.

Alderson, J.C. (2000). Assessing Reading (1st ed.). Cambridge, England: Cambridge University Press.

Berman, R.A. (1984). Syntactic Components of the Foreign Language Reading Process. In J.C. Alderson, \& A.H. Urquhart (Eds.), Reading in a Foreign Language (pp.139-159). London, England: Longman.

Bilá, M. (2016). K symetriám a asymetriám niektorých anglických a slovenských ekonomických termínov. On Symmetries and Asymmetries of Some English and Slovak Economic Terms. Foreign Languages in Changing Times VI, 13-19.

Bilá, M., Kačmárová, A., Kášová, M., Tomášiková, S., Vojtek, D., \& Koželová, A. (2015). Research on multiword expressions in the Germanic and Romance languages. In M. Ološtiak, (Ed.), Multiword expressions in Slovak (pp.57-77). Prešov, Slovakia: Faculty of Arts of Prešov University.

Breeze, R. (2007). Transparency in the Acquired Language Competences. Bratislava, Slovakia: Vydavatel'stvo EKONÓM.

Cooper, M. (1984). Linguistic competence of practised and unpractised non-native readers of English. In J.C. Alderson, \& A.H.Urquhart (Eds.), Reading in a Foreign Language (pp.122-138). Harlow, England: Longman.

Cotton, D., Falvey, D., \& Kent, S. (2011). Market Leader Business English Course Book Upper Intermediate. (3rd ed.). Harlow, England: Pearson Education Limited.

Cowie, A.P., Mackin, R., \& McCaig, I.R. (1993). Oxford Dictionary of English Idioms. Oxford, England: Oxford University Press

Delgadová, E. (2015). Reading literacy as one of the most significant academic competencies for university students. ProcediaSocial and Behavioral Sciences, 178, 48-53. https://doi.org/10.1016/j.sbspro.2015.03.145.

Donna, S. (2000). Teach Business English. Cambridge, England: Cambridge University Press.

Fernando, C. (1996). Idioms and Idiomaticity. Oxford, England: Oxford University Press.

Freebody, P., \& Anderson, R.C. (1983). Effects of vocabulary difficulty, text cohesion, and schema availability on reading comprehension. Reading Research Quarterly, XVIII (3), 277-294.

Gilakjani, A.P., \& Sabouri, N.B. (2016). A Study of Factors Affecting EFL Learners' Reading Comprehension Skill and the Strategies for Improvement. International Journal of English Linguistics, 6(5), 180-187. http://dx.doi.org/10.5539/ijel.v6n5p180

Gillet, A. (2010). Speak Business English Like an American: Learn the Idioms \& Expressions You Need to Succeed on the Job! Ann Arbor, Michigan: Language Success Press.

Gluchmanova, M. (2016). Using the Moodle Platform in English Teaching. TEM Journal, 5(4), 492-497. https://doi.org/10.18421/TEM54-13.

Hakim, M., Abidin, M., \& Bahari, A. (2020). Dictionary Use to Increase Students' Vocabulary Mastery: Electronic Dictionary or Printed One? Proceedings of the 1st Bandung English Language Teaching International Conference, 1, 150-159. https://doi.org/10.5220/0008215001500159.

Hoey, M. (2015). Words and their neighbours. In J.R. Taylor (Ed.), The Oxford Handbook of the Word (pp.141-156). Oxford, England: Oxford University Press.

Hrdličková, Z. (2016a). Immediate Context as a Linguistic Variable Influencing Understanding the Meaning of Phrasal Verbs. Foreign Languages in Changing Times VI, 41-48.

Hrdličková, Z. (2016b). Ideational Idioms in Business English Communication. Bratislava, Slovakia: Vydavatel'stvo EKONÓM.

Hrdličková, Z. (2017). Readability and vocabulary - The variables affecting text difficulty. From Here to There: Regional and World Perspectives on Language, Literature and Culture. Neophilologica Sandeciensia, 11, 17-27. 
Hrdličková, Z (2018). Promoting Media, Information and Reading Literacy Through a Business Communication E-course. In Beseda, J., \& Rohlíková, L. (Eds.), Disco 2018: Overcoming the Challenges and Barriers in Open Education, 13th conference reader (pp.178-198). Prague, Czech Republic: Centre for Higher Education Studies.

Hrdličková, Z., Rusiňáková, J., \& Maierová, E. (2019). Economic Concepts and Idioms in English Business Communication. České Budějovice, Czech Republic: College of European and Regional Studies, z.ú.

Kačmárová, A. (2011). A Concise English Grammar Course. (2nd ed.). Prešov, Slovakia: Faculty of Arts of Prešov University.

Kecskes, I. (2013). Intercultural Pragmatics. Oxford, England: Oxford University Press.

Kučerová, M., \& Fidlerová, H. (2012). Štatistické metódy. Statistical methods. Bratislava, Slovakia: Slovak University of Technology in Bratislava.

Lasić-Lazić, J., Ivanjko, T, \& Grubješić, I. (2017). Using Moodle in English for Professional Purposes (EPP) Teaching at the University North. Conference: 2017 40th International Convention on Information and Communication Technology, Electronics and Microelectronics (MIPRO) (pp.1021-1025). https://doi.org/10.23919/MIPRO.2017.7973553.

Law, J. (Ed.). (2015). Oxford Dictionary of Law. (2nd ed.). Oxford, England: Oxford University Press.

Maierová, E. (2018). Idioms in Marketing Communication. Lingua et Vita, 7(14), 24-30. Retrieved from https://linguaetvita.sk/www_write/files/issues/2018/14/d_03_24az30_jkk_maierova_142018.pdf

McCarthy, M., \& O’Dell, F. (2002). English Idioms in Use Intermediate. Cambridge, England: Cambridge University Press.

McCarthy, M., \& O'Dell, F. (2005). English Collocations in Use Intermediate. Cambridge, England: Cambridge University Press.

Mel'čuk, I. (2012). Phraseology in the language, in the dictionary, and in the computer. Yearbook of Phraseology, 3(1), 31-56. https://doi.org/10.1515/phras-2012-0003.

Moon, R. (1998). Fixed Expressions and Idioms in English: A Corpus Based Approach. Oxford, England: Clarendon Press.

Nattinger, J.R., \& DeCarrico, J.S. (1992). Lexical Phrases and Language Teaching. Oxford, England: Oxford University Press.

O’Dell, F., \& McCarthy, M. (2008). English Collocations in Use Advanced. Cambridge, England: Cambridge University Press.

O’Dell, F., \& McCarthy, M. (2010). English Idioms in Use Advanced. Cambridge, England: Cambridge University Press.

OECD. (2019a). PISA 2018 Results (Volume I): What Students Know and Can Do, PISA, OECD Publishing, Paris. https://doi.org/10.1787/5f07c754-en

OECD. (2019b). PISA 2018 Assessment and Analytical Framework, PISA, OECD Publishing, Paris. https://doi.org/10.1787/b25efab8-en

Parkinson, D., \& Noble, J. (Eds.). (2005). Oxford Business English Dictionary for Learners of English. Oxford, England: Oxford University Press.

Pellicer-Sánchez, A. (2015). Learning L2 collocations incidentally from reading. Language Teaching Research, 21(3), 1-22. https://doi.org/10.1177/1362168815618428

Peters, E. (2014). The effects of repetition and time of post-test administration on EFL learners' form recall of single words and collocations. Language Teaching Research, 18, 75-94. https://doi.org/10.1177/1362168813505384

Peters, E. (2015). The learning burden of collocations: The role of interlexical and intralexical factors. Language Teaching Research, 20(1), 1113-138. https://doi.org/10.1177/1362168814568131

Quirk, R., Greenbaum, S., Leech, G., \& Sartvik, J. (1985). A Comprehensive Grammar of the English Language. London, England: Longman Group Limited.

Rusiňáková, J. (2018). English idioms - theory and practice. Lingua et Vita, 7(14), 48-55. Retrieved from https://linguaetvita.sk/archiv-vydani/lingua-et-vita-14-2018\#jarmila-rusinakova.

Schlesinger, I.M. (1986). Sentence structure and the reading process. The Hague, The Netherlands: Mouton (Janua Linguarum 69).

Shaykina, O.I. (2015). Blended Learning in English Language Teaching: Open Educational Resources Used for Academic Purposes in Tomsk Polytechnic University. Mediterranean Journal of Social Sciences, 6(3), 255-259. https://doi.org/10.5901/mjss.2015.v6n3s5p255

Sonomura, M.O. (1996). Idiomaticity in the basic writing of American English. New York, New York: Peter Lang Publishing, Inc.

Spišiaková, M. (2017). Kontrastive Analyse der Phraseologismen und Metaphern: spanisch (Spanien) - slowakisch. In Macht der Sprache - Sprache der Macht: eine kontrastive mehrsprachige Analyse anhand von Korpustexten der meinungsbildenden Tageszeitungen mit Fokus auf Phraseologie und Metaphernforschung (S.119-162). Hamburg, Germany: Verlag Dr. Kováč.

Spišiaková, M. (2018). Contemporary Spanish Business Language. Lingua et Vita, 7(13), 42-54. Retrieved from https://linguaetvita.sk/archiv-vydani/lingua-et-vita-13-2018\#maria-spisiakova.

Spišiaková, M., \& Kittová, Z. (2020). Labour Market Requirement for Foreign Language Education with a Focus on Spanish. Advanced Education, 14, 29-37. https://doi.org/10.20535/2410-8286.196817

Strässler, J. (1982). Idioms in English: A pragmatic analysis. Tübingen, Germany: Narr.

Tang, J. (2013). The Research on Blended Learning of ESL Based on Moodle Platform. Studies in Literature and Language, 6(2), 30-34. https://doi.org/10.3968/j.sll.1923156320130602.3612

Taylor, K. (2006). Fifty ways to improve your Business English ... without too much effort! London, England: Summertown Publishing.

Walter, E. (Ed.). (2006). Cambridge Idioms Dictionary (2nd ed.). Cambridge, England: Cambridge University Press.

Webb, S., Newton, J., \& Chang, A. (2013). Incidental Learning of Collocation. Language Learning, 63, 91-120. https://doi.org/10.1111/j.1467-9922.2012.00729.x

Williams, R., \& Dallas, D. (1984). Aspects of vocabulary in the readability of content area L2 educational textbooks. In J.C. Alderson, \& A.H. Urquhart (Eds.), Reading in a Foreign Language (pp.199-212). London, England: Longman. 


\section{Appendix 1}

Write a 50-word summary of the text. (Source: Students' assignments (with mistakes) in "Business Communication" e-course in LMS Moodle)

\section{Student 1}

Summary 1

The article is about e-mail communication. There are advantages and disadvantages of e-mail communication. In Luke opinion, email is one of the most important communcation tool in bussines. (Posted: 2017, November 21, 9:07 p.m.)

\section{Summary 2}

In this article we can be learned about his luxury italian company. This company is from Italy and focus on sale luxury and excellent goods. His goods has been saled in China, India and other countries. (Posted: 2017, November 21, 9:19 p.m.)

\section{Student 2}

\section{Summary 1}

The article focuses on advantages and disadvantages of using E-mails. In E-mails you can do mistakes, people can misunderstand your feelings and emotion. Spoken words fade, but E-mails is forever. Everything is better to tell face to face or via phone, but Emails are still very important to our life. (Posted: 2017, November 15, 10:33 p.m.)

\section{Summary 2}

This article describes the company of Tod's Group, typical for its italian lifestyle. Its signature products like shoes and bags are made of raw materials or leather. For Mr Della Valle is important to put quality before quantity and be like luxury-goods company, not a fashion company, that why is Tod's so famous. (Posted: 2017, November 20, 5:21 p.m.)

\section{Summary 3}

This article examines how important connections are in a business world. In China, connections are translated as 'guanxi' and it is the key to successful business because it means loyalty, accontability and obligation. Guanxi is reason why lots of succesfull businessman in Asia are that succesfull. (Posted: 2017, November 26, 8:08 p.m.)

English Idioms Test (Source: Own)

\section{Appendix 2}

Market Leader Business English Course Book Upper Intermediate (Units 9-12)

Exercise 1 Complete the sentences with the appropriate form of an idiom from the box.

he who pays the piper calls the tune, hedge your bets, keep your ear to the ground, hard cash, to no avail, pay over the odds, throw good money after bad, bread-and-butter, pay lip service, easy money, get to the bottom of, keep an open mind, off the top of $s b$ 's head, give and take, pass the buck

1 He's the person responsible. He shouldn't try to $\ldots \ldots \ldots \ldots \ldots \ldots \ldots \ldots \ldots \ldots \ldots$ and blame others for his mistakes.

2 Because Ben is such a good writer, freelance work is ............................ for him.

3 It's a good idea to .............................. by applying to more than one MBA programme.

4 'There has been a good $\ldots \ldots \ldots \ldots \ldots \ldots \ldots \ldots \ldots \ldots \ldots . . \ldots \ldots \ldots \ldots$ back and forth with the organisations,' he says.

5 Once there, she spent months pitching to hundreds of potential investors ................................, only to get a lucky break at the end.

6 To provide more cash when no changes have been made to the faulty system would be to

7 By using customer service experts and the latest technology, these companies were able to focus on dealing with their business.

8 Some companies don't really care about career development, they just to it.

9 At the end of the day, though, their company is paying for the study, and ...

10 She started at the beginning in order to

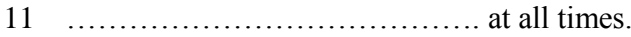

12 They're .............................. for the site, but it is a prime location.

13 Could you please tell me how many of these items you import each month? Oh, I don't know ......... A very large number, that's for sure.

$14 \ldots \ldots \ldots \ldots \ldots \ldots \ldots \ldots \ldots \ldots$ for information about the next fundraising event.

15 How much is it worth in ...............................?

Exercise 2 Translate the idioms into Slovak.

1 They say they're paying far too much and feel they have been ripped off

2 They developed the company by making top-of-the-range electronics products for higher-income groups.

3 Killing that drugs baron and his bodyguards gave me a real buzz

4 Follow his advice, and it'll be plain sailing.

5 Something which stops a negotiation going smoothly is a sticking point

6 If you or your bank account are in the red, you owe money to the bank.

7 Each side put their cards on the table, they identified what those potential problems were very early, and said if we can't get those, past those problems now, if we can't agree on what those problems are, if we can't agree about how we're going to deal with them once we have merged, then we shouldn't go through with this merger

8 Lend your money and lose a friend.

9 I was very put out indeed. It was all talk and no action.

10 Money talks in the Premiership and only the biggest spenders have any real hope of success. 
11 'You cannot be content with maintaining the status quo', Jones said. 'You must push the limits. Dare to be different!'

2 A short-term approach will not make an impact on revenues and profitability, so where should this investment be focused?

3 His idea was that delighting customers by over-exceeding their expectations should result in positive word of mouth for a company.

14 I know my colleague spoke at length this morning about body language, eye contact and the role of silence, but it's also important to bear in mind the social aspect.

15 But if the seller sets the expectations too high, he or she runs the risk that his or her buyers will be dissatisfied.

Appendix 3

Standardised Business English Test (Source: Department of English Language)

Market Leader Business English Course Book Upper Intermediate (Units 1-4)

I. Explain these expressions. (Total - 10 points)

buying spree; staff; competitive advantage; adapt; license

\section{Match a word/words from column A with their definitions from column B. (Total - 10 Points)}
A $\quad$ B
1 supplier A a new business that is started by two or more companies, often in the form of an independent company whose
shares they own
3 launch $\quad$ C a company, person, etc. that provides things that people want or need, especially over a long period of time
4 homogenous $\mathrm{D}$ much lower than usual
5 stockbroker E very distant
6 knock-down $\quad F$ an arrangement in which a group of people or an organisation have legal control of money or property for another person or group of people
7 venture capital $\mathrm{G}$ a person or an organisation that buys and sells share for other people
8 far-flung $\quad \mathrm{H}$ money that is invested in a new company to help it develop or expand, which may involve a lot of risk but can also bring good profits
9 joint venture I to start selling a product or service for the first time
10 accusation $\mathrm{J}$ consisting of people or things that are all of the same type

III. Complete the gaps in the sentences with a word/words from the above in column A. Make the appropriate changes if necessary. (Total -10 points)

1. They were forced to sell the business at a

2. But there's still plenty of price.

3. The company is now the main out there looking for bright new ideas.

4. The French company has a

5. The company is with Dongfeng Motor in China.

6. In classifying the aim is to sort objects by their selected properties into categories.

7. His administration now faces of corruption.

8. The money will be held in until she is 18

9. Our job is to organise the company's ___ offices.

10. More than 120 __ in Britain offer share-dealing services to private investors.

IV. Put each verb in brackets into a suitable tense. (Total - 10 points)
a) A: Tom 1 (think) of emigrating. B: What 2 (you/think) of the idea?

b) Will customers please make their way to the cash desk as the store 3 (close) in five minutes.

c) She sacked him before he 4 (have) a chance to explain his behaviour.

d) We 5 (work for) IBM for ten years by Christmas.

e) While I 6 (negotiate) the contract, my boss phoned me to say that he wanted completely different conditions.

f) We wanted to talk to the manager in charge but she 7 (just, leave).

g) We 9 ___ (receive) over 5,000 entries for the competition so far.

h) A: We've got a lot of bills to pay. B: I know. I 9

i) You won't be able to part here tomorrow; they 10 (do) them all next Monday. (mend).

V. Read the text and decide if the statements are true or false. (Total -10 points)

VI. Write down a summary of the main points of the text in 50 words. (Total - 10 points) 